\title{
PERFORMANCE OF BROILER CHICKS FED MASH OR PELLETED DIETS CONTAINING CORN-WITH-COBS MEAL WITH OR WITHOUT ENZYME SUPPLEMENTATION. El-Serwy, Amina A, ${ }^{1}$; M. S. Shoeib ${ }^{2}$ and I. A. Fathey ${ }^{2}$ 1- Poultry Prod. Dept., Fac. Agric., Mansoura Univ., Egypt \\ 2- Anim. Prod. Res. Inst., Agric. Res. Center, Egypt.
}

\section{ABSTRACT}

The objective of present study was to investigate the effect of feeding diets containing different levels $(0,15,30$ or $45 \%)$ of corn-with-cobs (CWC) meal in two forms (mash or pellets) with or without adding exogenous enzyme preparation (Sicozyme) on the broiler growth performance, carcass traits, blood constituents, and nutrient digestibility. Five hundred seventy-six Hubbard broiler chicks were randomly divided into 16 equal experimental groups; each contained 3 equal replications. The chicks were kept in brooding and growing batteries during the starter and finisher periods, 0-3 and 3-7 weeks of age. Sixteen starter and finisher experimental diets were formulated and used. Each experimental group was given its respective diet and all birds were managed similarly and had free access to feed and water. The results obtained can be summarized in the following:

Apart from the effect of diet form (DF) or enzyme addition (EA), feeding CWC-diets had no adverse effect on live body weight (LBW) or body weight gain (BWG) of broilers during the entire experimental period. When the dietary CWC level reached $45 \%$ feed intake $(\mathrm{FI})$ of broilers was significantly increased while feed conversion (FC) was negatively affected compared with their control counterparts. Birds fed pellets exhibited significantly better LBW and BWG than those of birds fed the mash diets, while FI and FC were not affected, regardless of the effect of dietary CWC level or EA. Similarly, LBW and BWG of broilers were positively affected due to dietary EA as compared to those of birds fed the un-supplemented diets, irrespective of the effect of DF or dietary CWC level. Increasing dietary CWC level to 30 or $45 \%$ adversely affected digestibilities dry matter, organic matter and crude protein and rate of nitrogen retention. Birds fed the pelleted diets had better digestibilities for crude protein and ether extract and nitrogen retention compared with those fed the mash diets. Dietary EA led to an increase in the rate of nitrogen retention. Carcass traits of broilers were not significantly affected by dietary CWC level with the exception of significant reductions in dressing-out and abdominal fat percentages and an increase in relative weight of gizzard for birds fed the 45\% CWC-diets compared with the controls. Dietary EA and DF had no effect on carcass traits, except that gizzard percent slightly reduced due to feeding pellets as compared to feeding the mash diets. There were significant reductions in serum levels of triglycerides, total cholesterol, and LDL-cholesterol for broilers fed the CWC-containing diets, particularly having the $45 \%$ level. However, blood parameters were not affected by EA or DF, with the exception of a significant decrease in triglycerides level in broilers fed pellets as compared to those fed the mash diets. Economic efficiency of broiler production was not affected by including CWC up to $30 \%$ in their diets; pelleting of diets and enzyme addition might have a beneficial effect.

It could be concluded that corn-with-cobs meal can be included up to $30 \%$ in diets of broilers without adverse effects on broiler performance; pelleting of diets and enzyme addition had positive effects in this respect.

Keywords: Corn-with-cobs meal, Pelleting, Sicozyme, Broiler performance, Carcass traits, Blood constituents, Nutrients digestibility, Economic efficiency. 


\section{INTRODUCTION}

Corn (Zea mays.) compared with other cereal grains is the preferable primary source in poultry diets. The continuous increase in human population worldwide, particularly in developing countries, is often associated with increasing the relative price of competitive animal and human feed- and foodstuffs, including corn, barley, rice and others. This necessary and urgent need to look for cheaper or untraditional alternative feedstuffs. Corn-withcobs meal (which is also termed corn ears or maize ears) is usually preferred to shelled maize because it is less likely to form a doughy mass in the stomach (FAO, 2004). It has been reviewed that the high fiber content of CWC meal restricted its use as a feed ingredient in poultry diets; however, pigs can tolerate the incorporation of such feed ingredient up to $25-50 \%$ in their diets, depending on age (FAO, 2004). In harmony with the general nutritional aspect that the nutritive value of any feed ingredient is essentially affected by its chemical composition, Martinez et al. (2008) reported that chemical compositions of maize ear and corn are similar, but maize ear has higher fiber content than corn. Also inclusion of maize ear in the diet of fattening rabbits increases the digestible energy content, reduces the voluntary feed intake and improves feed conversion ratio.

According to the available sources of literature, very limited information is presented on the nutritive value of CWC meal for poultry. In this regard, Scott et al. (1976) tabulated that CWC meal contains [(as dry matter (DM) basis] $7.5 \%$ crude protein (CP), $3 \%$ fat, $8.6 \%$ crude fiber (CF), $0.04 \%$ calcium, $0.2 \%$ total $\mathrm{P}, 0.07 \%$ available $\mathrm{P}, 0.18 \%$ histidine, $0.18 \%$ lysine, $0.16 \%$ methionine, $0.16 \%$ cystine, $0.45 \%$ arginine, $0.45 \%$ phenylalanine, $0.45 \%$ glycine, $0.36 \%$ valine, 0.36 isoleucine, $0.36 \%$ threonine, $1.0 \%$ leucine and $0.09 \%$ tryptophan, and it has a metabolizable energy (ME) of 2840 $\mathrm{kcal} / \mathrm{kg}$ DM. Recently, Martinez et al. (2008) reported that the composition of corn cobs was as follows: $94.2,1.94,2.23,0.471,38.0,86.1,45.3$ and 5.22\% for $\mathrm{DM}$, ash, CP, ether extract (EE), CF, neutral detergent fiber, acid detergent fiber and acid detergent lignin, respectively. On the other hand, Abou-Khashaba (1999) found that using corn-cobs plus enzyme in formulating broiler feeds supported growth, feed/gain ratio, carcass characteristics and blood constituents equivalent to that obtained by cornSBM diet. El-Serwy et al. (2009) fed laying hens dietary levels of CWC meal $(0,10,20$ and $30 \%)$ with or without Kemzyme supplementation and found that increasing dietary level of CWC positively affected feed conversion, however neither dietary enzyme supplementation nor diet form (mash vs. pellets) had a significant effect on body weight change, feed consumption, feed conversion or blood constituents of Silver Montazah laying hens. In general, we must bear in mind that the nutritive value of feedstuff for poultry can vary considerably depending upon its chemical composition and level of inclusion, composition and physical nature (i.e. particle size and texture) of the basal diet, type and age of experimental birds and/or other factors. Nowadays, most nutritionists formulate diets destined to poultry based completely on oil-seed meals, cereal grains and their by-products. Such plant 
feed ingredients naturally contain a variety of components. (i.e. anti-nutritional substances) that cannot be digested by monogastric animals because of the lack of or insufficiency of endogenous enzyme secretions. In addition to being unavailable to the animal, these components also lower the utilization of other dietary nutrients, leading to depressed performance. Recently, the inclusion of commercial enzymes into poultry diets has become a common practice, with different degrees of success depending upon the stress, health and nutritional state of the bird. Most feed used for broilers is heated and compressed to form pellets. Pelleting is associated with positive effects for feed handling and bird performance, including improved the efficiency of feed utilization and better growth rate (Leeson and Summers, 1991; Gibson, 1995), the main target for using feed enzymes is to increase digestibility (or availability) of nutrients, to break down the anti-nutritional factors to achieve the least cost feed formulations and for environmental reasons (Bedford, 1996, Bedford and Morgan, 1996, Bedford and Partridge, 2003).

Therefore, the present study was carried out to evaluate the response of broiler chicks to feeding mash and pelleted diets containing graded levels of corn-with-cobs meal with or without enzyme supplementation.

\section{MATERIALS AND METHODS}

The present study was carried out in Poultry Farm belonging to Poultry Production Department, Faculty of Agriculture, Mansoura University, Egypt. The experimental work aimed to study the effect of feeding graded dietary levels of corn with cobs meal without or with Sicozyme ${ }^{\circledR}$ supplementation in two diet forms (mash and pellets) on growth performance traits, nutrient digestibility, blood parameters and some carcass characteristic. A factorial experimental design $(4 \times 2 \times 2)$ which contains four levels of CWC meal $(0,15$, 30 and $45 \%$ of ration) and two levels of Sicozyme ( 0.0 and $1 \mathrm{~g} / \mathrm{kg}$ diet) in two forms (mash or pellets) was used. At one day of age, five hundred and seventy-six Hubbard broiler chicks were randomly chosen from a large population of broiler chicks and allocated randomly into 16 equal groups (36 chicks for each). Each experimental group was divided to three equal replications. The chicks were individually weighed at the beginning of the study and at 21 and 49 days of age. The initial average weight of chicks was $46.32 \pm 0.08 \mathrm{~g}$. Corn-soybean meal-based diets were used as controls. All the experimental diets were formulated to meet the nutrient requirements of broiler chicks (as recommend by NRC, 1994). Composition and proximate analysis of ingredients and the experimental diets used in this study, are presented in Table 1. Sicozyme is a multi-enzyme preparation which contained $\alpha$-amylase, $\beta$-glucanase, lipase and cellulase. Broiler chicks of the present experiment were reared during the experimental period in cages up to 49 days of age. Day-old chicks were vaccinated against New Castle disease using water soluble vaccines. Hitchner and Lasouta were earned out at 18 and 32 days of age. Continuous lighting was provided constantly throughout the experimental period, from one day up to 7 weeks of age. 
El-Serwy, Amina A, et al. 
Chicks in the experimental groups were subjected to the same managerial, environmental and hygienic conditions. The experimental rations were offered ad. libitum and fresh water was available all the time.

Individual live body weight, weight gain, feed consumption and feed conversion ratio ( $\mathrm{g}$ feed/g gain) were recorded at one, 21 and 49 days of age. At the end of the experimental period (49 days of age), a slaughter test was performed on 48 birds of similar body weight ( 3 birds from each group). All birds were starved for 12 hours before slaughtering. Birds were individually weighed, then they were slaughtered till complete bleeding. Feathers were then plucked, and viscera and legs were removed. The weights of carcass, giblets (heart, empty gizzard and liver), abdominal fat and dressing-out (weights of carcass plus giblets) were recorded as a percentage of live body weight. Blood samples were collected on the time of slaughtering from each bird. Blood was collected in tubes and used for the preparation of serum samples by centrifugation at 4000 r.p.m for 20 minutes and serum samples were stored at $-20^{\circ} \mathrm{C}$ pending analysis Determinations of serum total protein (Peters, 1968), cholesterol (Young and Friedman, 2001), total lipids (Tietz, 1987), HDL and LDL (Young and Friedman, 2001), triglycerides (Werner et al., 1981) were made using commercial kits. Thyroid gland hormones [triiodothyronine (T3) and thyroxine (T4)] were determined by RIA technique, as described by Sterling (1975); using commercial kits. Analyses were done at the laboratories of Animal Production Research Institute, Ministry of Agriculture, Egypt. When chicks were 6 weeks old digestion trials were initiated in order to evaluate the digestibility of nutrients in the experimental diets. Three chicks per treatment, having body weights around the average weight of the treatment, were selected, individually weighed and kept in metabolic cages. They were fed their respective experimental diet for a fourday pretest adaptation period, followed by a three-day test period where daily feed intake and excreta voided of the individual birds were quantitatively determined.

The proximate analysis of the experimental diets and dried excreta were carried out according to the Association of Official Analytical Chemists (AOAC, 1990), using duplicate samples for each nutrient. The procedure of Jakobsen et al. (1960) was used for estimating the fecal nitrogen. In excreta samples, urinary organic matter was determined according to Abou-Raya and Galal (1971). At the end of this work, the economical efficiency of the experimental diets was calculated from the net revenue (LE)/ total cost of chick (LE).

Data were analyzed using least square and maximum likelihood program of SAS (2003). Significant differences among means were identified by Duncan's multiple range test (Duncan, 1955).

\section{RESULTS AND DISCUSSION}

Aside from the effect of diet form or enzyme addition, broiler chicks fed diet containing $15 \%$ CWC had the heaviest live body weight (7 weeks of age) and body weight gain (0-7 weeks of age) followed by those fed the 
control diet and those fed the diet containing 30\% CWC while the group which fed diet containing 45\% CWC had the lowest values without significant differences among them. Broiler chicks fed the pelleted diets had significantly $(P \leq 0.05)$ the heaviest live body weight at 3 and 7 weeks and body weight gain at 0-3 and 0-7 weeks of age compared to those fed mash diets (Table 2 ), regardless of the effect of dietary CWC level or enzyme addition (EA). The addition of Sicozyme to the experimental diets significantly $(P \leq 0.05)$ improved body weight (7 weeks of age) and body weight gain (0-7 weeks of age), irrespective of the effect of diet form (DF) or dietary CWC level.

Increasing dietary level of CWC up to $45 \%$ led to a significant increase $(P \leq 0.05)$ in feed consumption of broilers during the periods of 3-7 and 0-7 weeks of age, regardless of the effect of DF or EA (Table 3). It is clear that feed conversion of birds was inversely related to the CWC level in the Diet; the groups fed the diets containing 0, 15 and 30\% CWC meal had better feed conversion values, in a descending order with no significant differences among them, compared with those of birds fed the $45 \%$ CWC diets. Apart from the effect of dietary CWC level or EA, broilers fed pellets consumed significantly $(P \leq 0.05)$ more feed $(0-3$ weeks of age) and had significantly better $(P \leq 0.05)$ feed conversion than those of birds fed the mash diets. Enzyme supplementation to experimental diets did not significantly affect feed consumption or feed conversion of chicks fed the experimental diets during the whole experimental period (Table 3 ), regardless of the effect of dietary level of CWC or DF.

There were significant interactions $(P \leq 0.05)$ between dietary level of CWC and DF on 3-week-old live body weight of chicks and on body weight gain of birds (0-3 weeks old). The DF by EA interactions were significant $(P \leq 0.05)$ on 7 -week-old live body weight of chicks and on total body weight gain of birds (0-7 weeks old). However, no significant differences were observed between all other first-order interactions or among the secondorder interactions (i.e. CWCx DFx EA).

We must bear in mind that there is no available publication in the literature regarding the effect of using CWC meal in poultry diets on their growth performance, nutrient digestibility, and carcass characteristics, but recently El-Serwy et al. (2009) reported that dietary levels of CWC meal in laying hen diets had no significant effects on body weight change, or feed consumption. Also they added that neither dietary enzyme supplementation nor diet form (mash vs. pellets) had significant effects on body weight change, feed consumption or feed conversion. Iheukwumere et al. (2009) suggested that feeding $5 \%$ corn cob meal in the finisher diet was not detrimental to the performance of broilers. Abou- Khashaba (1999) used different levels of corn cobs in broiler diets with or without enzyme supplementation. He stated that ground corn cobs plus enzyme supplementation coud support growth and feed conversion ratio equivalent to that obtained by control diet. The slight improvement in growth performance of broilers, observed herein, particularly during the finishing period in response to dietary enzyme supplementation may be resulted from more efficient digestion and/or utilization of nutrients since neither feed intake nor feed conversion was affected by dietary enzyme addition. 
J. Animal and Poultry Prod., Mansoura Univ., Vol.3 (3), March, 2012

2 


\section{El-Serwy, Amina A, et al.}

3 
The present results are in agreement with those obtained by Mohamed and Hamza (1991), Farrell and Martin (1998) and El-Goggary (2004) who indicated that enzymes addition failed to produce a positive effect on live body weight and feed conversion of broilers. On the other hand, pelleting the experimental diets improved broilers performance, similar results are obtained by Leeson and Summers (1991), Gibson (1995), Kilburn and Edwards (2001), El-Serwy (1997), El-Serwy et al. (2008) and El-Serwy et al. (2009). Also, Silveira et al. (2010) found that broilers fed pelleted diet gave higher body weight gain when compared to the ones fed mash diet. This response is probably due to the fact that pellets is characterized with a lesser ration waste and a higher nutrient density resulting from the pelletization process, whereas, feeding mash diets, depending on the granulometry, broilers select the biggest particles, which can result in nutritional imbalance and, hence, impair the performance.

It is noticed from the data in Table 4 that there was a significant $(P \leq 0.05)$ increase in percentage of gizzard and significant $(P \leq 0.05)$ decrease in relative values of dressing-out and abdominal fat to pre-slaughter weight with increasing dietary level of CWC meal when compared with the control group; while the other carcass characteristics (relative weights of carcass, liver, heart and giblets) did not significantly differ. Pelleting the experimental diets significantly $(P \leq 0.05)$ decreased the gizzard weight percentage; however EA had no significant effect on carcass traits measured in the present study (Table 4). There were significant $(P \leq 0.05)$ interactions between CWC level and DF for relative weights of gizzard and abdominal fat (Table 4).

Values of carcass traits of broiler chicks were not significantly affected by interaction between dietary CWC level and EA or interaction between EA and DF or interaction among CWC level, EA and DF at the end of experimental period (Table 4). The present results agree with the findings reported by Abou-Khashaba (1999) who stated that different levels of corn cobs with or without enzyme addition did not affect carcass dressing weight percentage. In laying Japanese quails, Abdel-Azeem (2005) found that increasing dietary crude fiber level significantly decreased carcass dressing and abdominal fat percentages. Zeweil et al. (2005) found that supplementing the diets with enzyme had no effects on carcass, liver, heart, gizzard or intestinal weight percentages of Japanese quail chicks. El-Serwy et al. (2008) stated that pelleting diets decreased gizzard weight percentage as compared to mash diets. Also, Hassan and EL-Sheikh (2010) and Hassan (2011) showed that ducklings fed pellets exhibited decreased gizzard $\%$ as compared with the mash-fed group.

As shown in Table 5, blood levels of triglycerides, total cholesterol and LDL- cholesterol of broiler chicks were significantly decreased $(P \leq 0.05)$ as dietary level of CWC increased while levels of glucose, total protein, total lipids, HDL-cholesterol, T3 and T4 were not affected, irrespective of the effect of DF or EA. Apart from the effect of dietary level of CWC or EA, broilers fed the pelleted diets had significantly lower $(P \leq 0.05)$ level of serum triglycerides than that of birds fed the mash diets, whereas other estimated blood serum parameters were not affected. 


\section{El-Serwy, Amina A, et al.}

4 
J. Animal and Poultry Prod., Mansoura Univ., Vol.3 (3), March, 2012

5 
Similarly, all blood serum parameters, measured herein, were not significantly affected by dietary EA, independently from the effect of dietary CWC level or DF. The interaction between dietary CWC level and EA was significant $(P \leq 0.05)$ for serum levels of triglycerides and $L D L-c h o l e s t e r o l$. The dietary CWC level by DF interaction was significant $(P \leq 0.05)$ on serum triglycerides. However, no significant differences were observed between all other firstorder interactions or among the second-order interactions on the blood parameters of broiler chicks. The decrease in serum cholesterol and triglycerides contents of birds fed the CWC-containing diets may be attributed to cholesterol-binding properties of dietary fibers that may reduce sterol absorption from the gut (Nakaue et al., 1980). The present results agree with those of Abdel-Azeem (2005) who indicated that plasma levels of cholesterol were significantly decreased by increasing dietary crude fiber level. However, El-Serwy et al. (2009) reported that feeding different levels of CWC with/without enzyme addition in mash or pelleted diets to laying hens did not significantly affect blood constituents. Similarly, El-Serwy et al. (2008) found that neither enzyme addition nor pelleting diets had a significant effect on blood parameters of broiler chicks. Similar results were obtained by Zeweil et al. (2005) who reported that enzyme supplementation had no significant effect on plasma total protein, total lipids or cholesterol of Japanese quail fed different levels of rice bran. In addition, El-Goggary (2004) found that there were no adverse effects of adding enzymes to diets containing rice bran and wheat bran combination on concentrations of blood plasma total lipids, triglycerides, glucose, total protein or cholesterol. On the other hand, Hassan et al. (2003) found that dietary enzyme supplementation increased concentration of serum total protein and total lipids in laying hens.

The effects of dietary treatments on nutrient digestibility of broiler chicks are shown in Table 6. As presented in Table 6, it was observed that digestibilities of DM and organic matter (OM) of broiler chicks were adversely affected $(P \leq 0.01)$ when dietary level of CWC increased to 30 or $45 \%$, regardless of the effect of DF or EA. In a similar manner, CP digestibility and rate of nitrogen retention were slightly, but significantly, $(P \leq 0.05)$ reduced when the level of CWC reached $45 \%$ while digestibilities of $C F$ and nitrogenfree extract (NFE) and ash retention rate were not affected. On the other hand, broilers fed the pelleted diets had slightly higher $(P \leq 0.05)$ means of ether extract $(\mathrm{EE})$ and $\mathrm{CP}$ digestibility and nitrogen retention rate compared with those of birds fed the mash diets whereas digestibilities of DM, OM, CF and NFE and rate of ash retention were not affected, irrespective of the effect of dietary level of CWC or EA. Dietary enzyme supplementation, however, led to a slight increase $(P \leq 0.05)$ in rate of nitrogen retention but negatively affected $(P \leq 0.05)$ CF digestibility and had no effect on the digestibility of DM, $\mathrm{OM}, \mathrm{CP}, \mathrm{EE}$ and NFE or the rate of ash retention, apart from the effect of dietary level of CWC or DF. There were significant interactions between dietary CWC level and DF on DM and OM digestibility $(P \leq 0.01)$ and $C P$ digestibility $(P \leq 0.05)$. The dietary $C W C$ level by $E A$ interactions were significant $(P \leq 0.01)$ on $D M$ and OM digestibility. The interactions between DF and $E A$ were significant on rate of nitrogen retention $(P \leq 0.01)$ and $E E$ digestibility $(P \leq 0.05)$. All other first-order interactions had no significant 
effects on nutrient digestibility measured in this study. The effects of secondorder interactions were significant $(P \leq 0.05)$ only on the rate of nitrogen retention and the digestibility of $\mathrm{DM}$ and $\mathrm{OM}$. These results agree with the findings of Khempaka et al. (2009) who showed that nutrient digestibility decreased with increasing levels (0 to $16 \%)$ of dried cassava pulp $(13.59 \%$ fiber) in broiler chicks. Hassan and El-Sheikh (2010) reported that digestion coefficients of EE were significantly higher for ducks fed pellets and granules in comparison with those fed the control mash diet. However, digestion coefficients of OM, CF and NFE were not significantly affected. El-Ghamry et al. (2004) observed that Bovans layers fed diet supplemented with Kemzyme $(0.05 \%)$ exhibited no significant differences in the nutrients digestibility among the experimental groups, except for crude fiber digestibility at 52 weeks of age. El-Serwy et al. (2008) found that enzyme supplementation increased $\mathrm{CP}, \mathrm{OM}$ and NFE digestibility while diet form did not significantly affect the OM, CF, NFE, EE digestibility. Also El-Husseiny et al. (2006) and Zanella et al. (1999) stated that dietary phytase supplementation could improve the digestibility of CP, CF, and NFE in broiler chicks. Ghozlan (2009) reported that layer hen fed diets containing (10 and $20 \%$ ) CWC in mash or pelleted diets with/ without enzyme supplementation had the higher CP digestibility compared to those fed $30 \%$ CWC whereas diet form did not significantly affect nutrient digestibility.

Based on inputs and outputs used in estimating the economic efficiency of broiler production in this experiment, the data may indicate that inclusion of CWC up to $30 \%$ had no adverse effect on the economic efficiency of birds; pelleting of diets and enzyme addition might have some beneficial effects in this respect (Table 7). Shazly (2008) found that broiler chicks fed on pelleted diets achieved significantly better economical efficiency as compared to feeding the mash diets. Ghazalah et al. (2005) reported that dietary enzyme supplementation had positive effect on reducing the feed cost $/ \mathrm{kg}$ body weight gain as well as the economic efficiency for broiler chicks. Ghozlan (2009) found that laying hens fed pelleted diet containing $15 \%$ corn with cobs meal with enzyme exhibited the best net revenue and economic efficiency compared with their control birds.

\section{Conclusion:}

It could be concluded that up to $30 \%$ corn-with-cobs meal can be included in a diet without detrimental effects on growth performance of broilers. Pelleting of diets and enzyme addition might have a beneficial effect in this respect. 
El-Serwy, Amina A, et al. 
J. Animal and Poultry Prod., Mansoura Univ., Vol.3 (3), March, 2012 


\section{REFERENCES}

Abdel-Azeem, F.A. (2005). Studies on the effect of different crude fiber levels on laying Japanese quail (Coturnix Coturnix Japonica). Egypt Poultry Sci., 25:11, 241-257.

Abou- Khashaba, H.M. (1999). Nutritional studies on broiler rations. Ph.D. Thesis, Fac. Agric., Zagazig Univ., Egypt.

Abou-Raya, A.K. and A.G. Galal (1971). Evaluation of poultry feeds in digestion trials with reference to some factors involved. UAR J. Anim. Prod., 11(1): 207-221.

Adrizal, P.E. Palo and J.L. Sell (1996). Utilization of defatted rice bran by broiler chickens. Poultry Science, 75(8): 1012-1017.

Association of Official Analytical Chemists (AOAC, 1990). Official Methods of Analysis. 15th Ed. Published by AOAC, Washington, DC, USA.

Bedford, M.R. (1996). The effect of enzymes on digestion. J. Appl. Poultry Res., 5: 370-378.

Bedford, M.R. and A.J Morgan (1996). The use of enzymes in poultry diets. World's Poultry Sci. J., 52: 61-68.

Bedford, M.R. and G.G Partridge (2003). Enzymes in Farm Animal Nutrition. Edited by Bedford, M.R. and G.G Partridge, CAB International Publishing, Finnfeeds Marlborough Wiltshire, UK.

Duncan, D.B. (1955). The multiple range and multiple $F$ tests. Biometrics, 11; $1-42$.

El-Ghamry, A.A.; A.T. El-Yamany and Hewida M.H. El-Allawy (2004). Partial replacement of yellow corn by rice polishings and sugar beet pulp in laying hens diet supplemented with Kemzyme. Egypt. Poultry Sci., 24: $1-14$.

El-Goggary, M.R.S (2004). Physiological and nutritional studies on poultry. M.Sc. Thesis. Faculty of Agric., Mansoura University, Egypt.

El-Husseiny, O.M.; S. Abou El-Wafa and M. Shabaan (2006). Influence of dietary phytase on broilers performance fed low-phosphorus corn/soybean or sunflower diets based on digestible or deficient amino acid. Egypt. Poultry Sci, 26 (11): 427-454.

El-Serwy, Amina A. (1997). The effect of replacing commercial soybean meal by extruded full-fat soybeans in mash and pelleted diets on broiler performance. J. Agric. Sci. Mansoura Univ., 22 (5): 1443-1454.

El-Serwy, Amina A; Mervet A. Ali; M.M Khalifah and Soheir A. Shazly (2008). The influence of enzyme supplementation and pelleting of diets containing different levels of rice bran and wheat bran combination on broiler performance. J. Agri. Sci, Mansoura Univ., 33(6): 4037-4062

El-Serwy, Amina A; M.H. Rabie; S.A. Dorgham and M.E. Ghozlan. (2009). Performance of Silver Montazah hens fed mash or pelleted diets containing corn-with-cobs meal with or without enzyme supplementation. J. Agri. Sci. Mansoura Univ., 34(4): 2747-2761.

FAO (2004). Animal Feed Resources Information System. Zea mays N 549 FAO. Roma. Pp:1-4. www. Fao. Org/ag/aga/agap/frg/afris/data/549.htm. 
Farrell. D.J. and E.A. Martin (1998). Strategies to improve the nutritive value of rice bran in poultry diets. III. The addition of inorganic phosphorus and a phytase to duck diets. Br. Poultry Sci., 39 (5): 601-611.

Ghazalah A.A., A.H. Abd El-Gawad, M.S. Soliman and Amany. W. Youssef (2005). Effect of enzyme preparation on performance of broilers fed corn-soybean meal based diets Egypt Poult. Sci., Vol 25: 295- 316.

Ghazalah, A.A; O.M. El-Husseiny; H.M. Fayek and S. Abou-El-Wafa (1994). Influence of enzyme preparations and growth promoters on broilers performance. The Second Scientific Conf. on Poultry, Kafr El-Sheikh, Egypt, pp.140-165.

Ghozlan, M. El-Sayed (2009). A study on the effects of some nutritional factors on productivity of poultry. Ph. D Thesis, Faculty of Agric., Mansoura University, Egypt.

Gibson, K. (1995). The pelleting stability of animal feed enzymes $\ln : 2^{\text {nd }}$ European Symposium on Feed Enzymes. NoordwiJ Kerhout, Netherlands, 25-27 Oct., 1995.

Hassan, Mona M. (2011). Influence of date stone meal particle size and form of diet on Muscovy ducklings performance. Egypt. Poultry Sci., 31: 361 377.

Hassan, Mona M. and S.E.M. EL-Sheikh (2010) Effect of physical form of diets on the performance of ducks. Egypt. Poultry Sci., 30: 989-1002.

Hassan, R.A., E.H. El-Ganzoury, F.A. Abd El-Ghany and M.A. Shehta (2003). Influence of dietary zinc supplementation with methionine or microbial phytase enzyme on productive and reproductive performance for Mandarah strain. Egypt. Poultry Sci., 23 (IV): 761-785.

Iheukwumere, F.; E. Ndubuisi and E. Mazi (2009). Effect of feeding corn cob meal on the growth, nutrient digestibility and organ characteristics of finisher broilers. International Journal of Natural and Applied Sciences, Vol 5, No 1 (Abstr.).

Jakobsen, P.E., K. Gertov S. and H. Nielson (1960).Digestibility trials with poultry. Bretning fraforsos laboratoriet udgivet of kopenhaven stants.1The digestive tract of the hen and the technical problems encountered digestibility trials. Beretn.Forsgsiab. No. 322 pp.56.

Khempaka, S.; W. Molee and M. Guillaume (2009). Dried cassava pulp as an alternative feedstuff for broilers: Effect on growth performance, carcass traits, digestive organs, and nutrient digestibility. J. Appl. Poultry Res., 18: 487-493.

Kilburn, J. and H.M. Edwards (2001). The response of broilers to the feeding of mash or pelleted diets containing maize of varying particle sizes. Br. Poultry Sci., 42: 484-492.

Leeson, S. and J.D. Summers (1991). Commercial Poultry Nutrition. Univ. Books, Guelph, Ontario, Canada.

Martinez, M.; V.J. Moya; E. Blass and C. Carvera (2008). The use of maize ear in rabbit diets: nutritive value and effect on fattening performance. Agrociencia, 42(2): 151-156.

Mohamed, M.A. and A.S. Hamza (1991). Using enzyme preparation in cornsoybean meal broiler ration. Egypt. J. Anim. Prod., 28: 245-254. 
Nakaue, H.S; R.R. Lowry; P.R. Cheeke and G.H. Arscotit (1980). The effect of dietary alfalfa of varying saponin content on yolk cholesterol level and layer performance. Poultry Sci., 59(12): 2744-2748.

NRC; National Research Council (1994). Nutrient Requirements of poultry, 9th Rev. Edition, National Academy Press, Washington, DC,USA.

Peters, T. (1968). Proposals for standardization of total protein assays. Clin. Chem., 14: 1147-1159.

SAS Institute (2003). SAS User's Guide: Statistics. Version 8.2., SAS Institute Inc., Cary, NC.

Scott, M.L; M.C. Nesheim and R.J. Young (1976). Nutrition of the Chickens, 2nd edition, published by Scott, M.L. and Associates, Ithaca, New York.

Silveira, M.J.T. Zanusso; P. Rossi; F. Rutz; M.A. Anciuti; N.Zauk; C.L.G. Ribeiro; P.A.R. Brum and J.K. Nunes (2010). Effect of pelletization on diets containing an enzymatic complex for broiler chickens. Ci. Anim. Bras., Goiânia, 11: 326-333.

Soheir A. Shazly (2008). Effect of some environmental factors on productive performance of poultry. Ph. D. Thesis, Faculty of Agriculture, Mansoura University, Egypt.

Sterling, L. (1975). Diagnosis and Treatment of Thyroid disease, Cleveland CRC Press, pp.19-51.

Tietz, N.W. (1987). Fundamentals of Clinical Chemistry, $3^{\text {rd }}$ edition, published by W.B. Saunders Co., Philadelphia, PA.

Werner, M.; D. G. Gabrielson and J. Eastman(1981).Ultramicrodetermination of serum triglycerides by bioluminescent assay. Clin. Chem., 27(2): 268-271.

Young, D.S. and R.B. Friedman (2001). Effects of Disease on Clinical Lab.Tests, $4^{\text {th }}$ ed Washington, DC.: AACC Press.

Zanella, I; N.K. Sakomura; F.G. Silversides; A. Fiqueirdo and M. Pack (1999). Effect of enzyme supplementation of broiler diets based on corn and soybeans. Poultry Sci., 78: 561-568.

Zeweil, H.S; Salwa G.K. Genedy and N.S. Isshak (2005). Effect of rice bran and enzyme mixture supplementation on performance, digestibility and carcass traits of growing Japanese quails. Egypt. Poultry Sci., 25(11): 225-240.

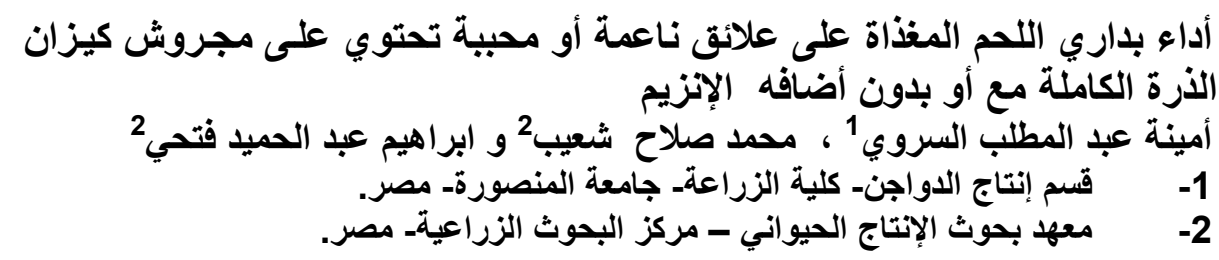

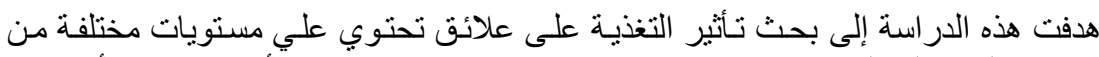

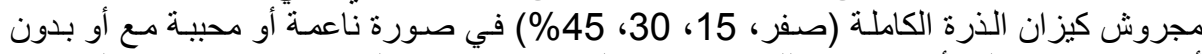

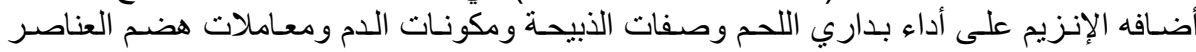

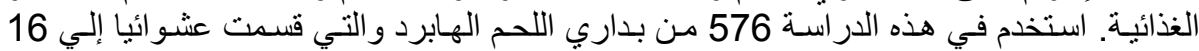
مجمو عة تجريبية كل منها يحتوي علي ثلاث مكررات منساوية. وربيت بداريت بداري اللحم في بطاريات 
خلال فترتي البادي و الناهي من صفر-3، 3-7 أسابيع من العمر ـ ونم التغذية على العلائق التجريبية

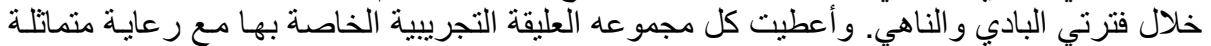

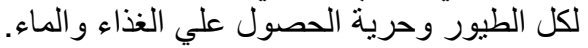

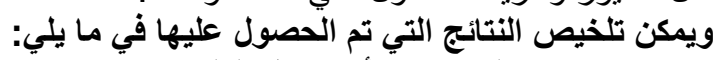

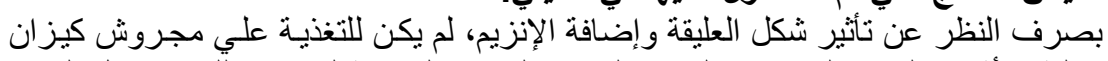

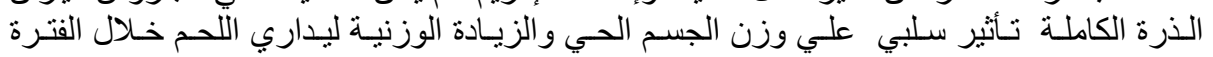

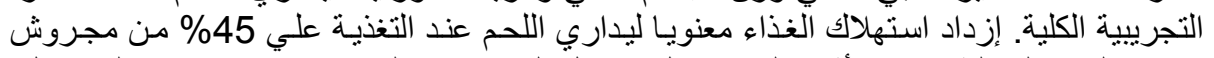

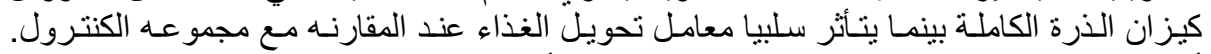

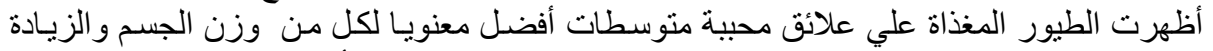

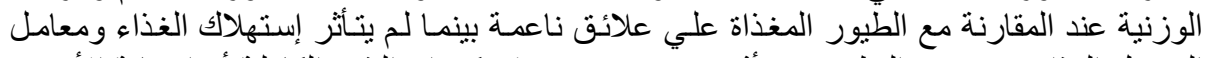

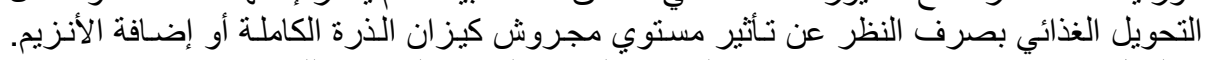

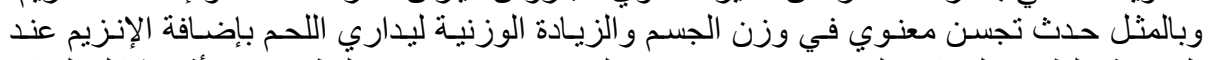

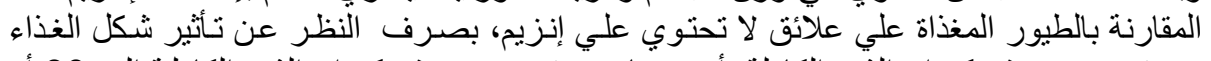

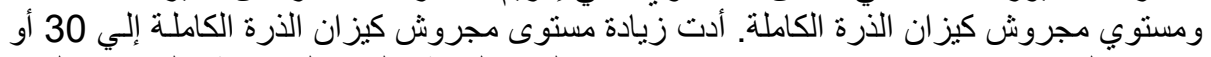

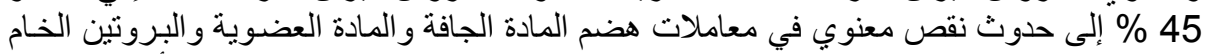

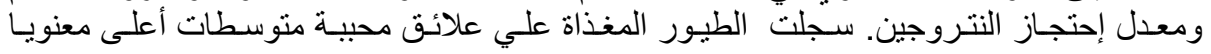

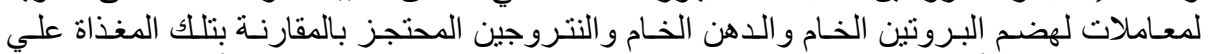

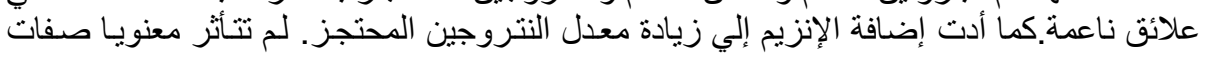

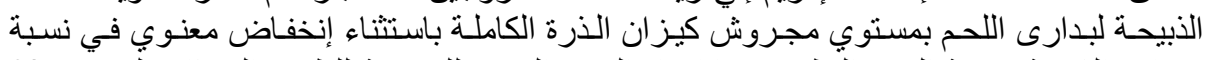

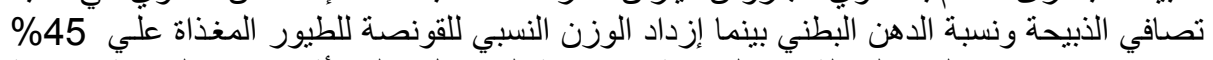

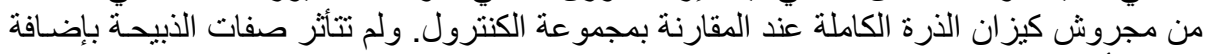

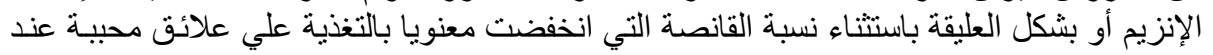

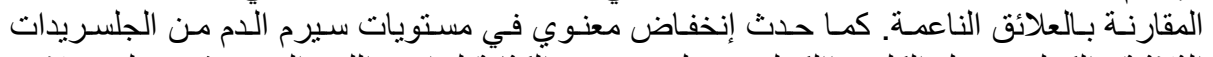

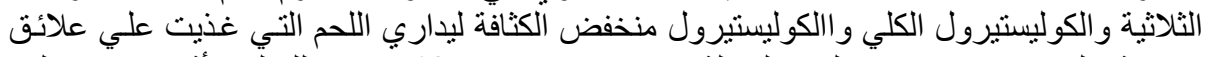

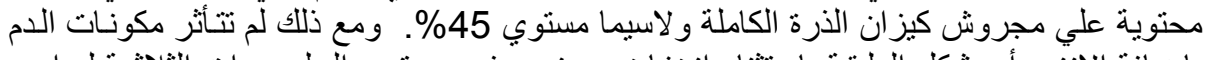

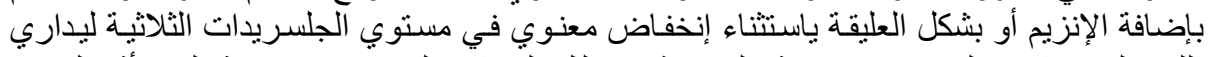

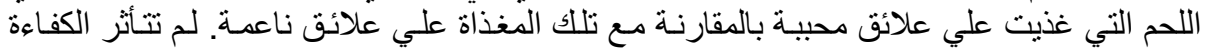

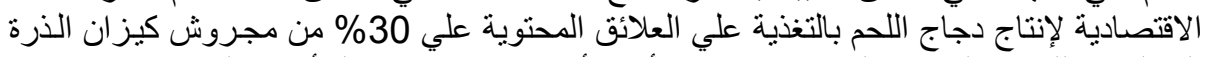

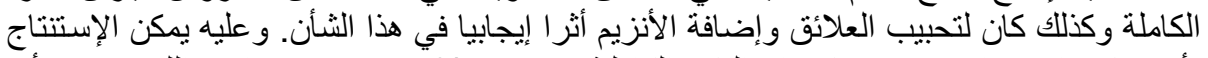

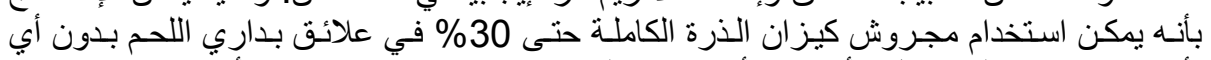

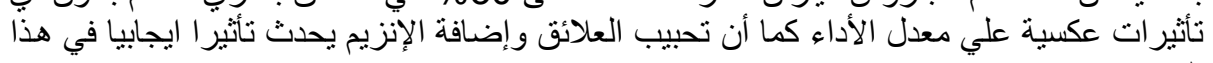

كلية الزراعة - جامعة المنصورة كلية الزراعة - جامعة دمنهور المنصورة
قام بتحكيم البحث

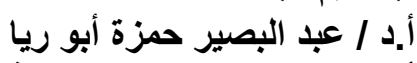
أ.د / أيوسف / عبد البصير الوهزب عطية 
Table (1): Formulation and composition of experimental diets during starter and finisher periods.

\begin{tabular}{|c|c|c|c|c|c|c|c|c|}
\hline \multirow{2}{*}{\begin{tabular}{|l|} 
Ingredients \% \\
Yellow corn \\
\end{tabular}} & \multicolumn{4}{|c|}{ Starter diets (0-3 wk) } & \multicolumn{4}{|c|}{ Finisher diets (3-7 wk) } \\
\hline & 60.00 & 45.00 & 30.00 & 15.00 & 65.00 & 50.00 & 35.00 & 20.00 \\
\hline Corn-with-cobs meal ${ }^{*}$ & 0.00 & 15.00 & 30.00 & 45.00 & 0.00 & 15.00 & 30.00 & 45.00 \\
\hline Soybean meal (44\% CP) & 29.70 & 26.60 & 23.50 & 20.30 & 27.73 & 24.73 & 21.73 & 18.63 \\
\hline Corn gluten meal $(62 \%$ CP) & 4.30 & 6.70 & 9.20 & 11.80 & 0.00 & 2.45 & 4.90 & 7.40 \\
\hline Dicalcium phosphate & 1.90 & 1.90 & 1.90 & 1.80 & 1.75 & 1.75 & 1.60 & 1.60 \\
\hline Cotton seed oil & 1.75 & 2.35 & 2.95 & 3.55 & 3.35 & 3.90 & 4.60 & 5.20 \\
\hline Salt & 0.30 & 0.30 & 0.30 & 0.30 & 0.30 & 0.30 & 0.30 & 0.30 \\
\hline Limestone & 1.35 & 1.35 & 1.35 & 1.39 & 1.15 & 1.15 & 1.15 & 1.15 \\
\hline Vit. \& Min. Premix ${ }^{\star \star}$ & 0.30 & 0.30 & 0.30 & 0.30 & 0.30 & 0.30 & 0.30 & 0.30 \\
\hline DL-Methionine & 0.30 & 0.30 & 0.30 & 0.30 & 0.22 & 0.22 & 0.22 & 0.22 \\
\hline L-Lysine-HCl & 0.10 & 0.20 & 0.20 & 0.26 & 0.20 & 0.20 & 0.20 & 0.20 \\
\hline Total & 100 & 100 & 100 & 100 & 100 & 100 & 100 & 100 \\
\hline \multicolumn{9}{|c|}{ Calculated analysis:( NRC, 1994) } \\
\hline Crude protein (CP) \% & 21.02 & 21.05 & 21.04 & 21.10 & 18.06 & 18.06 & 18.06 & 18.04 \\
\hline Crude fiber (CF) \% & 3.45 & 4.23 & 5.00 & 5.77 & 3.37 & 4.15 & 4.93 & 5.71 \\
\hline EE & 4.38 & 4.89 & 5.41 & 5.93 & 6.04 & 6.51 & 7.13 & 7.64 \\
\hline ME kcal/kg & 2987.91 & 2984.16 & 2979.53 & 2979.15 & 3081.18 & 3072.92 & 3076.66 & 3072.03 \\
\hline Ca \% & 1.03 & 1.02 & 1.01 & 1.00 & 0.92 & 0.91 & 0.87 & 0.86 \\
\hline Avalable P\% & 0.49 & 0.48 & 0.48 & 0.45 & 0.45 & 0.45 & 0.41 & 0.41 \\
\hline Lysine & 1.12 & 1.16 & 1.10 & 1.10 & 1.11 & 1.06 & 1.00 & 0.94 \\
\hline Methionine+ cystine & 0.94 & 0.95 & 0.97 & 0.99 & 0.76 & 0.77 & 0.79 & 0.81 \\
\hline \multicolumn{9}{|c|}{ Determined analysis (As feed: AOAC, 1990) } \\
\hline Moisture & 9.38 & 9.41 & 9.52 & 9.53 & 9.59 & 9.53 & 9.61 & 9.45 \\
\hline Ash & 5.61 & 5.72 & 5.75 & 6.01 & 5.53 & 5.80 & 5.90 & 6.19 \\
\hline Crude protein (CP) \% & 20.79 & 20.83 & 20.84 & 20.92 & 17.85 & 17.86 & 17.88 & 17.89 \\
\hline Crude fiber (CF) \% & 3.56 & 4.38 & 5.19 & 6.00 & 3.48 & 4.30 & 5.12 & 5.94 \\
\hline EE \% & 3.96 & 4.52 & 5.09 & 5.66 & 5.62 & 6.14 & 6.81 & 7.38 \\
\hline NFE \% & 56.70 & 55.14 & 53.61 & 51.88 & 57.93 & 56.37 & 54.68 & 53.15 \\
\hline Price/kg diet; L.E. & 2.29 & 2.26 & 2.21 & 2.17 & 2.28 & 2.22 & 2.18 & 2.12 \\
\hline
\end{tabular}

Pelleting and enzyme addition add 0.05 and $0.04 \mathrm{LE}$ to the price per $\mathrm{kg}$ diet illustrated above.

*: The nutrient composition of corn and cobs meal was calculated according to Scott et al. (1976): $7.5 \%$ crude protein, $3.0 \%$ fat, $8.6 \%$ crude fiber, $0.04 \%$ calcium, $0.20 \%$ total $P, 0.07 \%$ available $P, 0.18 \%$ lysine, $0.16 \%$ methionine and it has a metabolizable energy of $2840 \mathrm{kcal} / \mathrm{kg}$ DM..

**Each $3.0 \mathrm{Kg}$ of the Vit. and Min. premix manufactured by Agri-Vet Company, Egypt and contains : Vit. A, 12000000 IU ; Vit. D3 2000000 IU ; Vit. E, $10 \mathrm{~g}$; Vit. K3, $2.0 \mathrm{~g}$; Vit. B1, $1.0 \mathrm{~g}$; Vit. B2, $5 \mathrm{~g}$; Vit. B6, $1.5 \mathrm{~g}$; Vit. B12,10 mg ; choline chloride, $250 \mathrm{~g}$; biotin, $50 \mathrm{mg}$; folic acid, $1 \mathrm{~g}$; nicotinic acid , $30 \mathrm{~g}$; Ca pantothenate, $10 \mathrm{~g} ; \mathrm{Zn}, 50 \mathrm{~g} ; \mathrm{Cu}, 10 \mathrm{~g} ; \mathrm{Fe}, 30 \mathrm{~g} ; \mathrm{Co}, 100 \mathrm{mg}$; Se, $100 \mathrm{mg} ; \mathrm{I}, 1 \mathrm{~g} ; \mathrm{Mn}, 60 \mathrm{~g}$ and anti-oxidant, $10 \mathrm{~g}$, and complete to $3.0 \mathrm{Kg}$ by calcium carbonate. 
J. Animal and Poultry Prod., Mansoura Univ., Vol.3 (3), March, 2012

Table (2): Body weight and body weight gain of broiler chicks as affected by dietary treatments and their interactions from 1-42 days of age.

\begin{tabular}{|c|c|c|c|c|c|c|}
\hline \multirow{2}{*}{ Treatments } & \multicolumn{3}{|c|}{ Body weight(g) } & \multicolumn{3}{|c|}{ Body weight gain(g feed/g gain) } \\
\hline & 1 day & 3 wks. & 7 wks. & $0-3 w k s$. & 3-7 wks. & 0 -7 wks. \\
\hline \multicolumn{7}{|c|}{ Corn with cobs meal levels (CWC) } \\
\hline $0 \%$ & $46.19 \pm 0.17$ & $570.92 \pm 9.50$ & $1877.67 \pm 18.02$ & $524.73 \pm 9.52$ & $1306.75 \pm 13.93$ & $1831.48 \pm 17.98$ \\
\hline $15 \%$ & $46.37 \pm 0.12$ & $558.08 \pm 9.52$ & $1887.25 \pm 20.51$ & $511.71 \pm 9.48$ & $1329.17 \pm 18.58$ & $1840.88 \pm 20.55$ \\
\hline $30 \%$ & $46.16 \pm 0.08$ & $547.83 \pm 12.01$ & $1849.00 \pm 21.40$ & $501.67 \pm 12.03$ & $1301.17 \pm 20.56$ & $1802.84 \pm 21.45$ \\
\hline $45 \%$ & $46.56 \pm 0.16$ & $530.42 \pm 9.10$ & $1813.83 \pm 23.93$ & $483.85 \pm 9.11$ & $1283.42 \pm 17.08$ & $1767.27 \pm 23.92$ \\
\hline Sig. & NS & NS & NS & NS & NS & NS \\
\hline \multicolumn{7}{|l|}{ Diet form(DF) } \\
\hline Mash & $46.37 \pm 0.11$ & $540.50 \pm 7.78^{b}$ & $1831.42 \pm 14.70^{b}$ & $494.13 \pm 7.79^{b}$ & $1290.92 \pm 12.21$ & $1785.05 \pm 14.71^{b}$ \\
\hline Pellets & $46.28 \pm 0.11$ & $563.13 \pm 6.59^{a}$ & $1882.46 \pm 14.74^{\mathrm{a}}$ & $516.85 \pm 6.59^{a}$ & $1319.33 \pm 12.46$ & $1836.18 \pm 14.77^{a}$ \\
\hline Sig. & NS & * & * & * & NS & * \\
\hline \multicolumn{7}{|c|}{ Enzyme addition (EA) } \\
\hline $0 \mathrm{~g}$ & $46.42 \pm 0.11$ & $547.17 \pm 7.70$ & $1834.42 \pm 15.73^{\mathrm{b}}$ & $500.75 \pm 7.70$ & $1287.25 \pm 13.94$ & $1788.00 \pm 15.75^{b}$ \\
\hline $1 \mathrm{~g} / \mathrm{kg}$ & $46.23 \pm 0.10$ & $556.46 \pm 7.34$ & $1879.46 \pm 14.08^{\mathrm{a}}$ & $510.23 \pm 7.36$ & $1323.00 \pm 10.00$ & $1833.23 \pm 14.09^{a}$ \\
\hline Sig. & NS & NS & * & NS & NS & * \\
\hline \multicolumn{7}{|l|}{ Interactions } \\
\hline CWC x DF & NS & * & NS & * & NS & NS \\
\hline CWC X EA & NS & NS & NS & NS & NS & NS \\
\hline EA x DF & NS & NS & * & NS & NS & * \\
\hline CWCx DFx EA & NS & NS & NS & NS & NS & NS \\
\hline
\end{tabular}

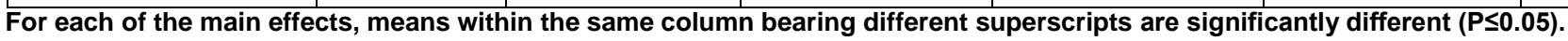


Table (3): Feed consumption and feed conversion of broiler chicks as affected by dietary treatments and their interactions at different age intervals.

\begin{tabular}{|c|c|c|c|c|c|c|}
\hline \multirow[t]{2}{*}{ Treatments } & \multicolumn{3}{|c|}{ Feed consumption (g) } & \multicolumn{3}{|c|}{ Feed conversion (g feed:g gain) } \\
\hline & 0-3wks. & 3-7 wks. & 0 -7 wks. & 0-3wks. & 3-7 wks. & 0 -7 wks. \\
\hline \multicolumn{7}{|c|}{ Corn with cobs meal levels (CWC) } \\
\hline $0 \%$ & $791.50 \pm 10.95$ & $3086.83 \pm 24.30^{b}$ & $3878.33 \pm 21.99^{b}$ & $1.51 \pm 0.03$ & $2.36 \pm 0.02$ & $2.12 \pm 0.01^{\mathrm{b}}$ \\
\hline $15 \%$ & $800.58 \pm 9.22$ & $3149.92 \pm 26.23^{\mathrm{ab}}$ & $3950.50 \pm 20.16^{\mathrm{ab}}$ & $1.57 \pm 0.03$ & $2.38 \pm 0.04$ & $2.15 \pm 0.03^{b}$ \\
\hline $30 \%$ & $793.33 \pm 11.78$ & $3158.83 \pm 25.55^{\mathrm{ab}}$ & $3952.17 \pm 28.35^{\mathrm{ab}}$ & $1.59 \pm 0.05$ & $2.44 \pm 0.05$ & $2.20 \pm 0.03^{\mathrm{ab}}$ \\
\hline $45 \%$ & $803.67 \pm 10.06$ & $3193.50 \pm 27.27^{a}$ & $3997.17 \pm 34.28^{\mathrm{a}}$ & $1.67 \pm 0.05$ & $2.49 \pm 0.03$ & $2.27 \pm 0.04^{\mathrm{a}}$ \\
\hline Sig. & NS & * & * & NS & NS & * \\
\hline \multicolumn{7}{|l|}{ Diet form(DF) } \\
\hline Mash & $806.50 \pm 6.89$ & $3119.79 \pm 18.69^{b}$ & $3926.29 \pm 19.97$ & $1.64 \pm 0.03^{\mathrm{a}}$ & $2.42 \pm 0.03$ & $2.20 \pm 0.02$ \\
\hline Pellets & $788.04 \pm 7.41$ & $3174.75 \pm 18.57^{a}$ & $3962.79 \pm 20.52$ & $1.53 \pm 0.03^{b}$ & $2.41 \pm 0.03$ & $2.16 \pm 0.02$ \\
\hline Sig. & NS & * & NS & * & NS & NS \\
\hline \multicolumn{7}{|c|}{ Enzyme addition (EA) } \\
\hline $0 \mathrm{~g}$ & $799.83 \pm 8.07$ & $3136.21 \pm 18.14$ & $3936.04 \pm 19.64$ & $1.61 \pm 0.03$ & $2.44 \pm 0.03$ & $2.21 \pm 0.02$ \\
\hline $1 \mathrm{~g} / \mathrm{kg}$ & $794.71 \pm 6.64$ & $3158.33 \pm 20.50$ & $3953.04 \pm 21.37$ & $1.57 \pm 0.03$ & $2.39 \pm 0.02$ & $2.16 \pm 0.02$ \\
\hline Sig. & NS & NS & NS & NS & NS & NS \\
\hline \multicolumn{7}{|l|}{ Interactions } \\
\hline CWC X DF & NS & NS & NS & * & NS & * \\
\hline CWC X EA & NS & NS & NS & NS & NS & * \\
\hline EA x DF & * & NS & NS & * & NS & NS \\
\hline CWCxDFx EA & NS & NS & NS & NS & NS & NS \\
\hline
\end{tabular}

For each of the main effects, means within the same column bearing different superscripts are significantly different $(\mathrm{P} \leq 0.05)$. 
J. Animal and Poultry Prod., Mansoura Univ., Vol.3 (3), March, 2012

Table (4): Carcass traits $(\bar{X} \pm S E)$ of broiler chicks as affected by dietary treatments and their interactions at 7 weeks of age.

\begin{tabular}{|c|c|c|c|c|c|c|c|c|}
\hline Treatments & $\begin{array}{c}\text { Pre-slaughter } \\
\text { weight (g) }\end{array}$ & Carcass $\%$ & Liver\% & Gizzard\% & Heart $\%$ & Giblets\% & Dressing\% & $\begin{array}{c}\text { Abdominal } \\
\text { fat } \%\end{array}$ \\
\hline \multicolumn{9}{|c|}{ Corn with cobs meal levels (CWC) } \\
\hline $0 \%$ & $1796.25 \pm 2.31$ & $69.24 \pm 0.51$ & $2.73 \pm 0.06$ & $2.26 \pm 0.04^{b}$ & $0.611 \pm 0.006$ & $5.61 \pm 0.07$ & $74.85 \pm 0.55^{a}$ & $1.98 \pm 0.01^{\mathrm{a}}$ \\
\hline $15 \%$ & $1799.17 \pm 2.81$ & $69.07 \pm 0.45$ & $2.66 \pm 0.06$ & $2.37 \pm 0.05^{\mathrm{ab}}$ & $0.602 \pm 0.008$ & $5.63 \pm 0.09$ & $74.71 \pm 0.44^{\mathrm{a}}$ & $1.91 \pm 0.03^{\text {ab }}$ \\
\hline $30 \%$ & $1793.75 \pm 2.69$ & $69.26 \pm 0.61$ & $2.68 \pm 0.03$ & $2.40 \pm 0.06^{\mathrm{ab}}$ & $0.603 \pm 0.007$ & $5.68 \pm 0.08$ & $74.94 \pm 0.63^{\mathrm{a}}$ & $1.91 \pm 0.03^{\mathrm{ab}}$ \\
\hline $45 \%$ & $1792.08 \pm 2.26$ & $67.22 \pm 0.71$ & $2.59 \pm 0.06$ & $2.48 \pm 0.04^{\mathrm{a}}$ & $0.591 \pm 0.009$ & $5.66 \pm 0.07$ & $72.88 \pm 0.75^{b}$ & $1.85 \pm 0.03^{b}$ \\
\hline Sig. & NS & NS & NS & * & NS & NS & * & * \\
\hline \multicolumn{9}{|l|}{ Diet form(DF) } \\
\hline Mash & $1793.33 \pm 1.52$ & $68.80 \pm 0.43$ & $2.64 \pm 0.04$ & $2.44 \pm 0.04^{a}$ & $0.603 \pm 0.005$ & $5.68 \pm 0.06$ & $74.48 \pm 0.45$ & $1.93 \pm 0.02$ \\
\hline Pellets & $1797.29 \pm 2.00$ & $68.60 \pm 0.44$ & $2.69 \pm 0.04$ & $2.32 \pm 0.03^{b}$ & $0.600 \pm 0.006$ & $5.61 \pm 0.05$ & $74.20 \pm 0.45$ & $1.90 \pm 0.02$ \\
\hline Sig. & NS & NS & NS & * & NS & NS & NS & NS \\
\hline \multicolumn{9}{|c|}{ Enzyme addition (EA) } \\
\hline $0 \mathrm{~g}$ & $1793.96 \pm 1.75$ & $68.38 \pm 0.49$ & $2.63 \pm 0.04$ & $2.37 \pm 0.04$ & $0.596 \pm 0.005$ & $5.59 \pm 0.05$ & $73.98 \pm 0.51$ & $1.93 \pm 0.02$ \\
\hline $1 \mathrm{~g} / \mathrm{kg}$ & $1796.67 \pm 1.85$ & $69.01 \pm 0.36$ & $2.70 \pm 0.04$ & $2.39 \pm 0.03$ & $0.607 \pm 0.005$ & $5.70 \pm 0.05$ & $74.71 \pm 0.37$ & $1.90 \pm 0.02$ \\
\hline Sig. & NS & NS & NS & NS & NS & NS & NS & NS \\
\hline \multicolumn{9}{|l|}{ Interactions } \\
\hline CWC x DF & NS & NS & NS & * & NS & NS & NS & * \\
\hline CW C X EA & NS & NS & NS & NS & NS & NS & NS & NS \\
\hline EA $\times$ DF & NS & NS & NS & NS & NS & NS & NS & NS \\
\hline CWCxDFx EA & NS & NS & NS & NS & NS & NS & NS & NS \\
\hline
\end{tabular}

For each of the main effects, means within the same column bearing different superscripts are significantly different $(P \leq 0.05)$ 
Table (5): Blood serum biochemical parameters $(\bar{X} \pm S E)$ of broiler chicks as affected by dietary treatments and their interactions at 7 weeks of age.

\begin{tabular}{|c|c|c|c|c|c|c|c|c|c|}
\hline Treatments & $\begin{array}{c}\text { Glucose } \\
(\mathrm{mg} / 100 \mathrm{ml})\end{array}$ & \begin{tabular}{|c|} 
Total protein \\
(g/dl)
\end{tabular} & \begin{tabular}{|l|} 
Total lipids \\
(mg/100ml)
\end{tabular} & $\begin{array}{c}\text { HDL } \\
(\mathrm{mg} / 100 \mathrm{ml})\end{array}$ & \begin{tabular}{|c|} 
LDL \\
(mg/100ml)
\end{tabular} & $\begin{array}{c}\text { Total } \\
\text { Cholesterol } \\
\text { (mg/100ml) }\end{array}$ & $\begin{array}{c}\text { Triglycerides } \\
(\mathrm{mg} / 100 \mathrm{ml})\end{array}$ & $\begin{array}{c}\text { T3 } \\
\mathrm{nmol} / \mathrm{L}\end{array}$ & $\begin{array}{c}\text { T4 } \\
\mathrm{nmol} / \mathrm{L}\end{array}$ \\
\hline \multicolumn{10}{|c|}{ Corn with cobs meal levels (CWC) } \\
\hline $0 \%$ & $72.29 \pm 1.29$ & $4.94 \pm 0.27$ & $544.49 \pm 12.88$ & $46.14 \pm 1.50$ & $143.27 \pm 7.89^{a}$ & $177.72 \pm 4.50^{a}$ & $73.08 \pm 2.00^{\mathrm{a}}$ & $189.55 \pm 13.66$ & $22.79 \pm 1.50$ \\
\hline $15 \%$ & $71.73 \pm 1.31$ & $4.93 \pm 0.22$ & $531.96 \pm 14.99$ & $48.34 \pm 1.49$ & $130.78 \pm 6.74^{\text {ab }}$ & $163.08 \pm 4.23^{\text {ab }}$ & $66.25 \pm 2.35^{b}$ & $186.32 \pm 13.27$ & $23.89 \pm 1.40$ \\
\hline $30 \%$ & $71.04 \pm 1.38$ & $4.81 \pm 0.25$ & $525.80 \pm 14.66$ & $49.66 \pm 1.87$ & $122.59 \pm 6.84^{\text {ab }}$ & $162.86 \pm 4.03^{\text {ab }}$ & $64.75 \pm 2.20^{5}$ & $166.31 \pm 11.57$ & $25.77 \pm 1.29$ \\
\hline $45 \%$ & $71.91 \pm 1.41$ & $4.67 \pm 0.34$ & $517.79 \pm 13.71$ & $51.92 \pm 1.55$ & $113.99 \pm 5.90^{6}$ & $158.42 \pm 4.80^{6}$ & $62.00 \pm 2.07^{b}$ & $141.33 \pm 11.74$ & $23.10 \pm 1.30$ \\
\hline Sig. & NS & NS & NS & NS & * & * & * & NS & NS \\
\hline \multicolumn{10}{|l|}{ Diet form (DF) } \\
\hline Mash & $72.01 \pm 0.99$ & $4.77 \pm 0.20$ & $530.89 \pm 10.37$ & $49.23 \pm 1.17$ & $130.67 \pm 5.47$ & $166.14 \pm 3.37$ & $69.38 \pm 1.63^{a}$ & $160.12 \pm 9.28$ & $25.03 \pm 0.90$ \\
\hline Pellets & $71.48 \pm 0.89$ & $4.91 \pm 0.18$ & $529.13 \pm 9.67$ & $48.80 \pm 1.21$ & $124.64 \pm 4.87$ & $164.91 \pm 3.38$ & $63.67 \pm 1.71^{D}$ & $181.63 \pm 9.79$ & $22.75 \pm 0.98$ \\
\hline Sig. & NS & NS & NS & NS & NS & NS & * & NS & NS \\
\hline \multicolumn{10}{|c|}{ Enzyme addition (EA) } \\
\hline $0 \mathrm{~g}$ & $70.93 \pm 0.97$ & $4.75 \pm 0.16$ & $522.86 \pm 9.81$ & $49.12 \pm 1.16$ & $126.10 \pm 4.70$ & $163.16 \pm 3.44$ & $64.58 \pm 1.79$ & $162.86 \pm 9.68$ & $24.62 \pm 0.93$ \\
\hline $1 \mathrm{~g} / \mathrm{kg}$ & $72.56 \pm 0.89$ & $4.93 \pm 0.21$ & $537.16 \pm 10.02$ & $48.92 \pm 1.22$ & $129.22 \pm 5.66$ & $167.88 \pm 3.24$ & $68.46 \pm 1.66$ & \begin{tabular}{|l|}
$178.89 \pm 9.62$ \\
\end{tabular} & $23.15 \pm 0.98$ \\
\hline Sig. & NS & NS & NS & NS & NS & NS & NS & NS & NS \\
\hline \multicolumn{10}{|l|}{ Interactions } \\
\hline CWC x DF & NS & NS & NS & NS & NS & NS & * & NS & NS \\
\hline CWC $\times$ EA & NS & NS & NS & NS & * & NS & * & NS & NS \\
\hline EA x DF & NS & NS & NS & NS & NS & NS & * & NS & NS \\
\hline CWCx DFxEA & NS & NS & NS & NS & NS & NS & NS & NS & NS \\
\hline
\end{tabular}

For each of the main effects, means within the same column bearing different superscripts are significantly different $(P \leq 0.05)$. 
Table (6): Nutrient digestibility $(\bar{X} \pm S E)$ of broiler chicks as affected by dietary treatments and their interactions at 7 weeks of age.

\begin{tabular}{|c|c|c|c|c|c|c|c|c|}
\hline \multirow{2}{*}{ Treatments } & \multicolumn{6}{|c|}{ Nutrient digestibility (\%) } & \multirow[b]{2}{*}{$\mathrm{N}$ retention $\%$} & \multirow[b]{2}{*}{$\begin{array}{c}\text { Ash retention } \\
\%\end{array}$} \\
\hline & DM & OM & $\mathrm{CP}$ & $\mathrm{EE}$ & CF & NFE & & \\
\hline \multicolumn{9}{|c|}{ Corn with cobs meal levels (CWC) } \\
\hline $0 \%$ & $72.02 \pm 0.17^{\mathrm{a}}$ & $81.70 \pm 0.13^{\mathrm{a}}$ & $85.69 \pm 0.28^{a}$ & $81.02 \pm 0.20$ & $19.23 \pm 0.70$ & $84.30 \pm 0.18^{b}$ & $64.64 \pm 0.28^{a}$ & $20.76 \pm 0.32$ \\
\hline $15 \%$ & $71.82 \pm 0.20^{a}$ & $81.69 \pm 0.17^{a}$ & $85.72 \pm 0.25^{a}$ & $81.18 \pm 0.16$ & $18.86 \pm 0.63$ & $85.25 \pm 0.25^{a b}$ & $64.43 \pm 0.26^{a}$ & $20.87 \pm 0.33$ \\
\hline $30 \%$ & $70.84 \pm 0.29^{b}$ & $80.72 \pm 0.28^{b}$ & $85.21 \pm 0.17^{\text {ab }}$ & $80.91 \pm 0.16$ & $17.80 \pm 0.56$ & $85.11 \pm 0.37^{\mathrm{ab}}$ & $63.99 \pm 0.23^{a b}$ & $20.89 \pm 0.26$ \\
\hline $45 \%$ & $70.20 \pm 0.24^{b}$ & $80.26 \pm 0.24^{b}$ & $84.90 \pm 0.19^{b}$ & $80.96 \pm 0.17$ & $18.22 \pm 0.63$ & $85.59 \pm 0.34^{\mathrm{a}}$ & $63.65 \pm 0.31^{b}$ & $21.01 \pm 0.38$ \\
\hline Sig. & ** & ** & * & NS & NS & * & * & NS \\
\hline \multicolumn{9}{|l|}{ Diet form(DF) } \\
\hline Mash & $71.17 \pm 0.22$ & $81.04 \pm 0.17$ & $85.10 \pm 0.15^{b}$ & $80.83 \pm 0.11^{b}$ & $18.25 \pm 0.44$ & $85.13 \pm 0.21$ & $63.92 \pm 0.18^{b}$ & $20.73 \pm 0.22$ \\
\hline Pellets & $71.27 \pm 0.23$ & $81.14 \pm 0.22$ & $85.66 \pm 0.17^{a}$ & $81.20 \pm 0.12^{a}$ & $18.80 \pm 0.45$ & $85.00 \pm 0.25$ & $64.44 \pm 0.21^{a}$ & $21.04 \pm 0.22$ \\
\hline Sig. & NS & NS & * & * & NS & NS & * & NS \\
\hline \multicolumn{9}{|c|}{ Enzyme addition (EA) } \\
\hline $0 \mathrm{~g}$ & $71.17 \pm 0.22$ & $81.09 \pm 0.20$ & $85.55 \pm 0.17$ & $80.87 \pm 0.11$ & $19.32 \pm 0.44^{\mathrm{a}}$ & $85.20 \pm 0.25$ & $63.87 \pm 0.18^{b}$ & $20.72 \pm 0.24$ \\
\hline $1 \mathrm{~g} / \mathrm{kg}$ & $71.28 \pm 0.22$ & $81.09 \pm 0.19$ & $85.21 \pm 0.16$ & $81.17 \pm 0.12$ & $17.73 \pm 0.39^{b}$ & $84.92 \pm 0.19$ & $64.49 \pm 0.21^{a}$ & $21.05 \pm 0.20$ \\
\hline Sig & NS & NS & NS & NS & * & NS & * & NS \\
\hline \multicolumn{9}{|l|}{ Interactions } \\
\hline CWC $\times$ DF & $\star *$ & ** & * & NS & NS & NS & NS & NS \\
\hline CWC $\times$ EA & * * & ** & NS & NS & NS & NS & NS & NS \\
\hline EA x DF & NS & NS & NS & * & NS & NS & $\star *$ & NS \\
\hline CWCxDFx EA & * & * & NS & NS & NS & NS & * & NS \\
\hline
\end{tabular}

For each of the main effects, means within the same column bearing different superscripts are significantly different $(\mathrm{P} \leq 0.05)$. 
Table (7): Inputs and outputs used to estimate the economic efficiency of broiler chicks as affected by dietary treatments from 1 day to 7 weeks of age.

\begin{tabular}{|c|c|c|c|c|c|c|c|c|c|c|c|c|c|c|c|}
\hline Items & 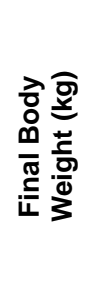 & 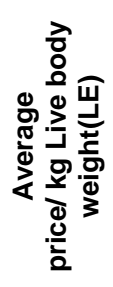 & 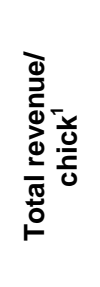 & 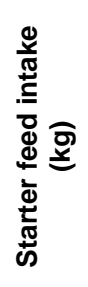 & 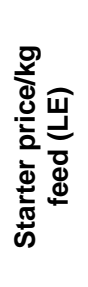 & 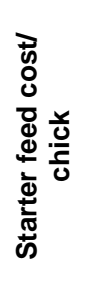 & 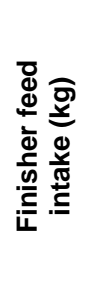 & 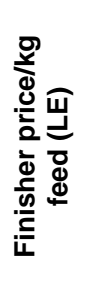 & 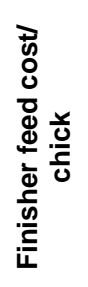 & 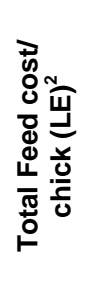 & 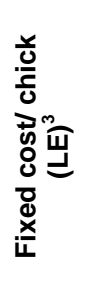 & 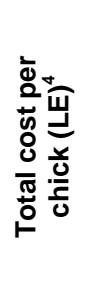 & 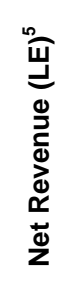 & 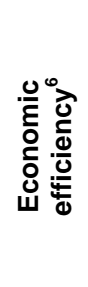 & 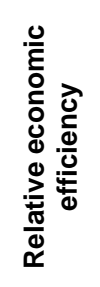 \\
\hline \multicolumn{16}{|c|}{ Corn with cobs meal levels (CWC) } \\
\hline $0 \%$ & 1.88 & 8.00 & 15.021 & 0.79 & 2.34 & 1.85 & 3.09 & 2.32 & 7.16 & 9.01 & 4.00 & 13.01 & 2.01 & 0.154 & 100.00 \\
\hline $15 \%$ & 1.89 & 8.00 & 15.10 & 0.80 & 2.31 & 1.85 & 3.15 & 2.27 & 7.15 & 9.00 & 4.00 & 13.00 & 2.10 & 0.161 & 104.55 \\
\hline $30 \%$ & 1.85 & 8.00 & 14.79 & 0.79 & 2.25 & 1.79 & 3.16 & 2.22 & 7.01 & 8.80 & 4.00 & 12.80 & 1.99 & 0.156 & 101.30 \\
\hline $45 \%$ & 1.81 & 8.00 & 14.51 & 0.80 & 2.22 & 1.78 & 3.19 & 2.17 & 6.93 & 8.71 & 4.00 & 12.71 & 1.80 & 0.141 & 91.56 \\
\hline \multicolumn{16}{|l|}{ Diet form(DF) } \\
\hline Mash & 1.83 & 8.00 & 14.65 & 0.81 & 2.25 & 1.81 & 3.12 & 2.22 & 6.93 & 8.74 & 4.00 & 12.74 & 1.91 & 0.150 & 100.00 \\
\hline Pellets & 1.88 & 8.00 & 15.06 & 0.79 & 2.30 & 1.81 & 3.17 & 2.27 & 7.21 & 9.02 & 4.00 & 13.02 & 2.04 & 0.157 & 104.67 \\
\hline \multicolumn{16}{|c|}{ Enzyme addition (EA) } \\
\hline $0 \mathrm{~g}$ & 1.83 & 8.00 & 14.68 & 0.80 & 2.26 & 1.81 & 3.14 & 2.22 & 6.96 & 8.77 & 4.00 & 12.77 & 1.91 & 0.149 & 100.00 \\
\hline $1 \mathrm{~g} / \mathrm{kg}$ & 1.88 & 8.00 & 15.04 & 0.79 & 2.30 & 1.83 & 3.16 & 2.26 & 7.14 & 8.97 & 4.00 & 12.97 & 2.07 & 0.160 & 107.38 \\
\hline
\end{tabular}

1- Total revenue per chick = Body weight $(\mathrm{Kg})$ /group X Price/ per $\mathrm{kg}$ live body weight (LE)

2- Total Feed cost/ chick (LE)2 = Feed cost/ chick (Starter) + Feed cost/ chick (Finisher)

3- Fixed cost $=$ Rearing cost + Initial price chick.

4- Total cost chick (LE) $4=$ Total Feed cost/ chick (LE) + Fixed cost/ chick (LE)

5-Net Revenue (LE) $5=$ Total revenue/ chick- Total cost/ chick (LE)

6-Economic efficiency6 = Net Revenue (LE)/ Total cost per chick (LE) 
J. Animal and Poultry Prod., Mansoura Univ., Vol.3 (3), March, 2012 